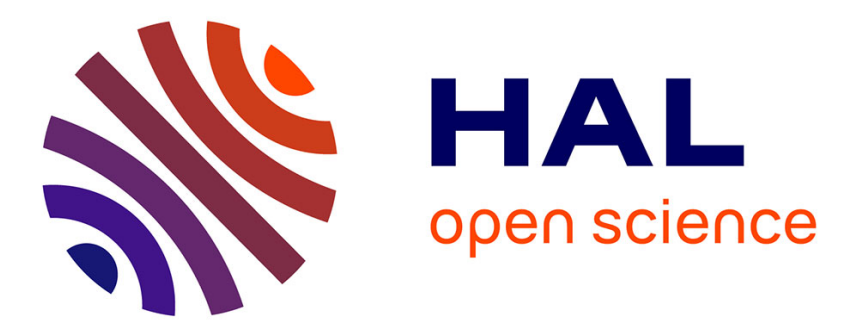

\title{
The spread of low-cost carriers: tourist and regional policy effects in Spain
}

\author{
J. Fernando Vera Rebollo, Josep Ivars Baidal
}

\section{To cite this version:}

J. Fernando Vera Rebollo, Josep Ivars Baidal. The spread of low-cost carriers: tourist and regional policy effects in Spain. Regional Studies, 2009, 43 (04), pp.559-570. 10.1080/00343400701874164 . hal-00516190

\section{HAL Id: hal-00516190 \\ https://hal.science/hal-00516190}

Submitted on 9 Sep 2010

HAL is a multi-disciplinary open access archive for the deposit and dissemination of scientific research documents, whether they are published or not. The documents may come from teaching and research institutions in France or abroad, or from public or private research centers.
L'archive ouverte pluridisciplinaire HAL, est destinée au dépôt et à la diffusion de documents scientifiques de niveau recherche, publiés ou non, émanant des établissements d'enseignement et de recherche français ou étrangers, des laboratoires publics ou privés. 


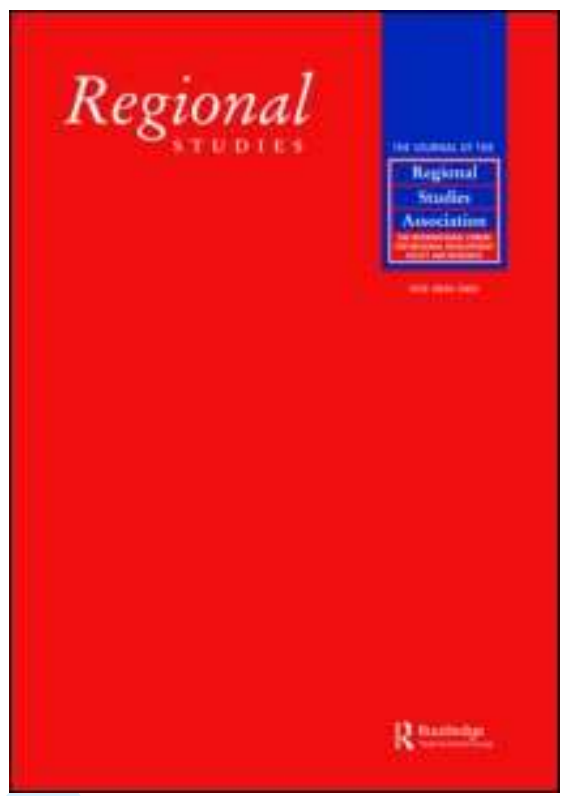

The spread of low-cost carriers: tourist and regional policy effects in Spain

\begin{tabular}{|r|l|}
\hline Journal: & Regional Studies \\
\hline Manuscript ID: & CRES-2006-0062.R2 \\
\hline Manuscript Type: & Main Section \\
\hline JEL codes: & $\begin{array}{l}\text { H54 - Infrastructures } \mid \text { Other Public Investment and Capital Stock < } \\
\text { H5 - National Government Expenditures and Related Policies }<~ H ~ \\
\text { Public Economics, L83 - Sports } \mid \text { Gambling|Recreation|Tourism }<\text { L8 } \\
\text { - Industry Studies: Services < L - Industrial Organization, L93 - Air } \\
\text { Transportation < L9 - Industry Studies: Transportation and Utilities } \\
\text { < L - Industrial Organization, R11 - Regional Economic Activity: } \\
\text { Growth, Development, and Changes < R1 - General Regional } \\
\text { Economics < R - Urban, Rural, and Regional Economics }\end{array}$ \\
\hline Keywords: & $\begin{array}{l}\text { air transport, airports, low-cost carriers, mobility, tourism, urban } \\
\text { growth }\end{array}$ \\
\hline
\end{tabular}

\section{SCHOLARONE \\ Manuscripts}




\section{THE SPREAD OF LOW-COST CARRIERS: TOURISM AND REGIONAL POLICY EFFECTS IN SPAIN}

\section{J. FERNANDO VERA REBOLLO and JOSEP A. IVARS BAIDAL}

Tourism Research Institute

Alicante University

Apdo. Correos 99

03080 Alicante (Spain)

Email: jf.vera@ua.es and josep.ivars@ua.es

First received: March 2006

Accepted: July 2007 


\begin{abstract}
LCCs form the most dynamic segment in the international tourism traffic toward Spain. Their recent evolution shows high growth rates which contrast with the stagnation of traditional companies, a phenomenon which is part of the transformations experienced by the tourism market and air transport in Europe and has caused both quantitative and qualitative changes in Spain's tourist activity. However, the effects of LCC operations go beyond the context of the tourism sector and affect land-use and infrastructure planning policies, gradually shaping a new scenario where the specialisation of tourism in real estate along the Spanish Mediterranean coast becomes reinforced.
\end{abstract}

KEY WORDS: air transport, low-cost carriers, airports, tourism, urban growth, mobility

JEL Classifications: H54, L83, L93, R11

Le développement des transporteurs à faible coût : effets du tourisme et de la politique régionale en Espagne

\title{
J. FERNANDO VERA REBOLLO et JOSEP A. IVARS BAIDAL
}

\section{RESUME}

Les transporteurs à faible coût (LCC) constituent le segment le plus dynamique du tourisme international vers l'Espagne. Leur évolution récente fait apparaître des taux de croissance élevés qui contrastent avec la stagnation des compagnies classiques, phénomène qui s'inscrit dans les transformations que connaissent le marché du tourisme 
et le transport aérien en Europe et qui est à l'origine de modifications quantitatives et qualitatives du tourisme en Espagne. Toutefois, les effets des opérations des LCC vont au-delà de ce secteur et touchent également les politiques d'aménagement du territoire et de planification des infrastructures, donnant naissance progressivement à un nouveau scénario où la spécialisation du tourisme dans l'immobilier le long des côtes méditerranéennes en Espagne se voit renforcée.

Mots-clés : transport aérien, transporteurs à faible coût, aéroports, tourisme, développement urbain, mobilité.

Classifications JEL : H54, L83, L93, R11

Die Ausbreitung von Billigfluggesellschaften: Auswirkungen auf Fremdenverkehr und Regionalpolitik in Spanien J. FERNANDO VERA REBOLLO and JOSEP A. IVARS BAIDAL

\author{
ABSTRACT \\ Billigfluggesellschaften bilden das dynamischste Segment des \\ internationalen Fremdenverkehrs in Spanien. Bei dieser neuen Entwicklung \\ werden hohe Wachstumsraten verzeichnet, während traditionelle \\ Gesellschaften eine Stagnation verzeichnen - ein Phänomen, das einen \\ Bestandteil des Wandels im Bereich des Fremdenverkehrsmarkts und \\ Flugverkehrs in Europa bildet und das zu einer quantitativen und qualitativen \\ Veränderung der touristischen Aktivitäten in Spanien geführt hat. Die \\ Auswirkungen der Geschäftstätigkeiten von Billigfluggesellschaften gehen \\ jedoch über den Kontext des Fremdenverkehrssektors hinaus und betreffen \\ auch die Politiken zur Planung von Bodennutzung und Infrastruktur, wobei \\ allmählich ein neues Szenario entsteht, in dem sich die Spezialisierung des \\ Fremdenverkehrs auf Immobilien entlang der spanischen Mittelmeerküste \\ verstärkt.
}




\section{KEY WORDS:}

Flugverkehr

Billigfluggesellschaften

Flughäfen

Fremdenverkehr

Städtewachstum

Mobilität

JEL Classifications: H54, L83, L93, R11 
RESUMEN

Las LCC’s constituyen el segmento más dinámico del tráfico turístico internacional hacia España. Su evolución reciente muestra elevadas tasas de crecimiento frente al estancamiento de las compañías tradicionales, un fenómeno que forma parte de las transformaciones que experimenta el mercado turístico y del transporte aéreo europeo y que ha provocado cambios cuantitativos y cualitativos en la actividad turística española. Sin embargo, sus efectos superan el ámbito sectorial-turístico para afectar a las políticas de ordenación del territorio y planificación de infraestructuras, configurando paulatinamente un nuevo escenario en el que se refuerza la especialización inmobiliaria del turismo en la costa mediterránea española.

PALABRAS CLAVE: transporte aéreo, compañías de bajo coste, aeropuertos, turismo, crecimiento urbanístico, movilidad 


\section{INTRODUCTION}

The appearance of low-cost carriers (LCCs) in Europe results from a combination of factors. Among them stand out the liberalisation of air transport in the European Union, the high fares applied by the former flag carriers, the existence of underused airports, the commercialisation through the Internet and the success of business projects such as Ryanair and Easyjet, which have managed to take advantage of the business opportunities derived from the evolution of air transport in this continent. The implementation of the Third Package of Air Transport Liberalisation Measures in 1997 allowed the development of LCCs, the number of which progressively increased together with the network of routes in Western Europe and later toward Central and Eastern Europe, made easier by the EU enlargement. The places offered by LCCs in Europe have passed from $4 \%$ to $23 \%$ in the 2001-2006 period (OAG, 2006), while BAKER et al. (2005) collect estimates which raise the LCC market share foreseen for 2010 to one third of the intraEuropean traffic.

This paper analyses the effects caused by the introduction of LCCs on Spain's tourist activity and on the policies associated with it from a regional perspective, assuming that this type of carriers is one of the most relevant change factors at the current tourist market. As the world's second largest international tourism receiving country (55.6 million arrivals in 2005), Spain has the highest LCC market penetration index in continental Europe $(22.7 \%$ of the Instrument Flight Rules -IFR- movement share between July and December 2006, according to the data provided by EUROCONTROL, 2006), with companies channelling $29.7 \%$ of international arrivals by air (51.4 million in all) (IET, 2006). 
In the first place, we review the scientific production that has studied the impact of LCC operations on the relationships between airports and airlines as well as their regional integration. This is the starting point for measuring the effects of low-cost traffic on the Spanish airport network and equally for checking that the effects on the volume and kind of traffic are different depending on the characteristics of each type of airport (hub, tourist and secondary). The influence on the traffic is related to the effects on tourist behaviour, which are evaluated comparing the behaviour patterns of tourists who travel with LCCs and those who do so with traditional companies through the examination of the results drawn from various demand studies.

In a rapidly evolving context, the paper describes the process of introduction of LCCs in Spain and their situation halfway through the present decade, a moment in which the high growth rates experienced during the 2001-2005 period tend to stabilise. LCC activity has consolidated in the international traffic of the Spanish airport network but its dynamism does not decrease, with all the implications this has for airport management, for the tourism sector and for the different associated public policies.

Following this approach, and after a previous summary of the regional policies related to tourism in Spain, an attempt is made to identify the effects on these policies generated by LCC operations. These effects go beyond the strictly tourist-sector framework, influencing infrastructure and land-use policies, above all along the Mediterranean coast. Within this framework, it becomes difficult to isolate the specific effects caused by LCC traffic on complex real-estate-based regional development processes or rather regional growth processes, but it is advisable to analyse the role played by LCCs on the intensification of some processes which have an undeniable socioeconomic and territorial relevance. In Atlantic Spain as well as at secondary airports that serve inland regions (Santander, Gijón, Granada, etc.), the interest lies in 
the opportunities to attract international tourism and in the link with economic diversification and urban restructuring policies.

\section{THE CONFIGURATION OF THE NEW AIRLINE-AIRPORT-REGIONAL}

\section{INTEGRATION RELATIONSHIPS}

A number of trends such as greater competition and air transport liberalisation, privatisation and globalisation have brought about changes in airline-airport relationships (GRAHAM, 2003), to which can be added the expansion of LCCs by the volume of traffic they generate and the specific requirements they pose for airports. The impact of LCC operations has not been felt in the main European hubs but in secondary airports within multi-airport systems serving metropolitan areas (Stansted and Luton in London, Hahn in Frankfurt or Charleroi in Brussels), regional airports and tourist airports with a variable volume of visitors. DOBRUSZKES (2005) warns about the gradual shaping of two networks in Western Europe: hub-and-spokes/FSNC (Full Service Network Carriers)/main airports vs. point-to-point/LCC/secondary airports, though it must be remembered that carriers such as Easyjet and Air Berlin operate at main airports and also that regional airports continue to be a staple supply source for the connecting flights that hubs concentrate on.

On the other hand, main airports do not fulfil the capacity, cost and functionality requirements demanded by LCCs, summarised by BARRETT (2004) in the following factors: reduced fees and charges; minimum stopover time (20-25 minutes); functional terminals for a quick check-in without the need to connect flights; good commercial and catering services; and good connectivity with land transport networks. Nevertheless, these requirements fit in with secondary airports, above all if they operate below their 
capacity. In these airports, the creation of new routes, the increase of frequencies and the reduction of fares make airport traffic grow, which in turn guarantees higher aeronautical and non-aeronautical revenues. In fact, the increased air connections can mean an enlargement of the airport's area of influence.

The higher traffic levels reinforce the airport's role in regional development, both from the point of view of its direct, indirect and induced economic impacts and in terms of its spin-off impact, though it is tremendously complicated to isolate the airport infrastructure's global impact or its specific influence as a business localisation factor (GRAHAM, 2003), bearing always in mind the twofold function of airports, i.e. as transport nodes and as an essential element in the regional economy (HAKFOORT et al., 2001).

ELFAA (2004) stresses the benefits that the presence of LCCs entails for regional development, which derive from the increased tourism, employment generation and firm localisation levels as a result of the greater number of passengers and links. LCC expansion would equally have prevented the unviability of secondary and regional airports abandoned by traditional airlines within their network strategy based on the hub-and-spoke system, and would even have contributed to a regional economic restructuring.

The airports with a higher LCC-penetration index show very high growth rates which would confirm a greater regional economic impact. Various studies highlight the positive impact on the regional economy that low-cost traffic growth has had in airports like Carcasonne and Cologne-Bonn (ELFAA, 2004), identify area of influence enlargement signs insofar as the competitive position of the airport is reinforced, as in Torp (Oslo) (GRAHAM, 1999) or Hannover (PANTAZIS and LIEFNER, 2005), and emphasise the role of the new air links in overcoming the costs of peripherality in the 
Scottish Highlands and Islands (SQW, 2002). The influence on the decisions related to business localisation in the region where the airport stands has received less attention, though it seems very limited in airports like that of Pisa (SIGNORINI et al. 2002).

Measuring the impact poses methodological difficulties and is hindered by the uneven effects of the different traffic types (international-domestic, long haul-short haul, passengers in connection, etc.), the characteristics of the airport and its area of influence and the regional economic structure. Furthermore, it is necessary to incorporate the airport's investment and maintenance costs, the impact of local residents who travel outside the region, the negative external effects (noise, pollution and safety risks) and the "crowding-out" effects, since the investment in the airport may prove beneficial to the region but not to the country as a whole (HAKFOORT et al., 2001). As for costs, they become reduced at airports used below their capacity where the increased LCC traffic makes possible a more efficient exploitation of the infrastructure, a circumstance which serves as an argument to justify the concession of public incentives. In certain cases, the airport has to be enlarged as a result of the continued traffic growth.

Although airport location is indisputably important, GRAHAM (1999) warns that the demand generation potential of each airport's area of influence no longer seems so relevant due to the new strategy of airlines, which establish their routes according to business interests. The airport-airline interdependence increases the convenience of strategic alliances such as the one between Lufthansa and the Munich airport analysed by ALBERS et al. (2005). The traffic increase caused by LCCs and their specific requirements favour a more contractual nature in the relationship with the airport operator (AVIATION STRATEGY, 2003). The new LCC-airport relationships include the adaptation to the type of operations required by LCCs as well as the reduction of both landing and handling fees which compensate the loss of aeronautical revenues with 
the growth of non-aeronautical revenues derived from the greater consumption of airport services (retail, catering, car-parking facilities, etc.) (PITT and BROWN, 2001; FRANCIS et al., 2003, 2004; GILLEN and LALL, 2004; BARRETT, 2004).

The agreements with LCCs entail evident risks for airports, though these risks vary depending on the bargaining power of each airport. GILLEN and LALL (2004) clearly differentiate the better bargaining position of Stansted, located in a metropolitan system with a high demand volume and several operating LCCs, as opposed to the case of regional airports where the traffic depends on a single LCC. The rise in the number of airports interested in attracting LCCs benefits these types of companies and allows them to replace one airport with another depending on which agreement is more advantageous to them. The interruption of the Ryanair routes in Kristenstad, Lamezia and Rimini following the upward revision of airport fees (GRAHAM, 2003) is a common practice. LCC volatility introduces an additional risk factor. The intensification of competition and the price war between LCCs and traditional carriers in 2004 are largely to blame for the recent failure of several LCCs in Europe (e.g. Now, Jet Green, VBird, Volare, Air Polonia and EU Jet). All forecasts suggest that the number of fifty LCCs currently operating in Europe will decrease considerably in the next few years.

Finally, the public incentives to the presence of LCCs in some airports have been questioned as a practice which distorts competition and creates discrimination between airlines, thus being incompatible with the Rome Treaty and the common market. After the decision made by the Commission (2004/393/EC), which declared illegal certain aids given to Ryanair by the Wallonia regional government and the Charleroi Airport Managing Entity (BSCA), the Communication of the EUROPEAN COMMISSION (2005) established the general principles for aids and subsidies at European airports. 


\section{THE IMPACT OF LOW-COST TRAFFIC ON THE SPANISH AIRPORT NETWORK}

The importance of tourist movements for the international air traffic in Spain and the level of LCC presence in the main markets emitting tourism toward Spain, i.e. the United Kingdom and Germany, which accumulated $28.9 \%$ and $17.8 \%$, respectively, of the international arrivals in 2005 (IET, 2006), explain the high traffic share of LCCs in Spain (22,7 of IFR movements). Traffic distribution across the Spanish airport network is dependent on international tourism flows. Madrid-Barajas and Barcelona-El Prat airports serve the two main metropolitan areas in the country and act as hubs for Spain's former flag company, Iberia. Particularly important is the case of Madrid, which receives 42 million passengers who might go up to 70 million with the enlargement works completed in 2006 -which will increase the number of movements/hour from 78 to 120 - and concentrates about $25 \%$ of Europe's links with Latin America (GÁMIR and RAMOS, 2002). Except for Madrid and Barcelona, the main Spanish airports in terms of traffic volume are located in coastal tourist regions (Palma de Mallorca, Málaga, Gran Canaria, Alicante and Tenerife Sur). Fig. 1 shows the distribution of the total passenger traffic by airport in 2005 and the percentage of international passengers who arrived in LCCs with respect to the total.

Fig. 1 Total passenger traffic and percentage of LCC international arrivals by airport (2005)

The tourist traffic toward Spain has traditionally been channelled through charter companies. However, the appearance of LCCs has largely modified the operations of 
tourist airports, as the international charter traffic has been replaced with the traffic of the scheduled flights typically operated by LCCs (WILLIAMS et al., 2003). For instance, the Alicante airport had $60 \%$ of the charter traffic as opposed to $10 \%$ corresponding to LCCs in 2000. However, in 2006, LCCs accumulate 53\% of the traffic and only $19 \%$ corresponds to charter companies. Nevertheless, a clarification must be made in relation to the scope of this apparent traffic diversion, because it is partly due to the re-branding of charter companies which have started operating as LCCs (e.g. Monarch Airlines, MyTravel Lite and Thomsonfly.com).

The evolution in the arrival of passengers coming from abroad with traditional carriers and LCCs (IET, 2004; 2006) proves the dynamism of the latter as well as their growing relevance in the international air traffic toward Spain. The average growth rate of LCCs during the 2001-2005 period reached $26.9 \%$ in contrast with the negative average rate of traditional companies $(-0.7 \%)$. This steady growth justifies the $29.7 \%$ share of all international arrivals in Spain during 2005 obtained by LCCs. The top three European LCCs, with over 3 million arrivals, took more than $60 \%$ of the traffic toward Spain with relatively homogeneous shares: Easyjet (21.2\%); Ryanair (20.9\%); and Air Berlin (20\%). Although with smaller shares, the British carriers Jet2 (5.6\%) and BmiBaby (3.5\%), the Dutch Transavia (6.3\%), the Danish Sterling European (3\%) and the Spanish Vueling (3\%) deserve to be mentioned as well.

The effects of LCC operations on Spain's airport network have essentially been felt at tourist airports, with a significant presence at Barcelona airport and a relatively limited one at Madrid airport, though in the latter case the enlargement of its capacity in 2006 may favour a greater presence of LCCs, which will probably be accompanied by a higher penetration of these carriers into domestic traffic too (specially taking into account the creation of Clickair, a Barcelona-based joint venture LCC with Iberia and 
the tour operator Iberostar as the two main shareholders $-20 \%$ of the shares eachtogether with three other partners). The Palma de Mallorca airport has the highest volume of arrivals with LCCs in absolute terms (3 million LCC international arrivals). This is so because Palma acts as a hub for Air Berlin, redistributing the traffic of the company between Germany and the tourist destinations in the Iberian Peninsula and the Canary Islands. In Málaga and Alicante, the LCC share goes up to $47.4 \%$ and $52.8 \%$ of the international arrivals, respectively, though the traffic volume is smaller. It is worth highlighting that the traffic with the United Kingdom predominates in these two airports, with the leadership of Easyjet, which accumulates nearly one third of the total LCC passengers.

Easyjet also achieves the highest low-cost traffic share in Barcelona (37.4\%), although this traffic only represents $26.9 \%$ of the international arrivals. However, this is symptomatic of LCCs operating in main airports (Easyjet, Air Berlin, Transavia, Vueling, etc). The Girona airport exceeds the figure of one million arrivals per year as a result of the presence of Ryanair, which concentrates $94 \%$ of the LCC passenger volume (that in turn accounts for $87 \%$ of the airport's total traffic). This airport has therefore been highly specialised in the low-cost traffic since it became a Ryanair base competing directly for the traffic to Barcelona, a city that is 101 kilometres away. It is undoubtedly the most evident example of the restructuring of international charter traffic from a markedly seasonal system linked to a coastal tourist space (Costa Brava) into a low-cost scheduled flight traffic system. This led to a dramatic rise in the number of passengers and to the expansion of the airport's area of influence to Barcelona's metropolitan system, served by a single airport until then. In fact, the city of Barcelona is the final destination for $26.7 \%$ of the passengers disembarking in Girona (MARTÍNEZ et al., 2004). 
The airports in the Canary Islands, with a considerable traffic volume linked to international tourism, cannot succeed in attracting LCC traffic volumes proportional to their international tourism arrivals. In 2005, the Canary Islands concentrated $18.9 \%$ of international tourism flows toward Spain but only $6.1 \%$ of LCC passenger arrivals. The long distance, more than three hours from the main emitting centres in the United Kingdom and Germany, directly affects the LCC business model and discourages the expansion of connecting routes with the Canary Islands.

The growth rate of international passenger arrivals with LCCs showed a reduction in $2005(30.8 \%)$, in contrast with the considerable rises experienced in $2003(64.1 \%)$ and $2004(47.6 \%)$. This indicates a stage of LCC traffic consolidation and stabilisation in Spain. With the exception of the explosive growth of Girona-Costa Brava in 2003 (4027.2\%), which went down to $156.8 \%$ in 2005 , airports with the highest rates roughly coincide with those which have a greater LCC traffic volume in absolute figures (Palma de Mallorca, Alicante, Málaga and Barcelona). However, once the traffic consolidated in these airports from 2004 on, it is the secondary airports that have shown the highest variation rates from clearly smaller entry flows. These growth rates coincide with the appearance of LCCs (Easyjet and Ryanair generated a 320.9\% growth at Valencia airport in 2005), with the enlargement of links (79.4\% in Murcia-San Javier) or with the establishment of companies at low-traffic airports subsidised by some regional governments in Atlantic Spain (the agreement with Ryanair in Santander-Parayas airport meant 36,799 international arrivals in 2004 , a growth rate of $16.936 .6 \%$, which went down to $315.5 \%$ in 2005). At secondary airports with a scarce international traffic, the impact of LCC operations shows in the generation of a significant volume of new demand. The Granada airport represents a symptomatic case. In 2005, the year in which Ryanair and Monarch started operating, 233,590 passengers registered with these 
companies, that is, $97 \%$ of the airport's international traffic; additionally, $44.5 \%$ of the tourists who have travelled to Granada with LCCs would have not visited the city if this type of flights did not exist, according to a survey carried out by ESECA (2006) with 400 British passengers in December 2005 and January 2006.

\section{THE EFFECTS OF LCC OPERATIONS ON TOURIST ACTIVITY}

LCC expansion has contributed to the positive evolution of international tourism flows toward a mature tourist destination, Spain, during the last five years, with a $15.2 \%$ growth rate in international air passenger arrivals between 2001 and 2005. In addition to this quantitative effect, the influence exerted by these companies combined with other factors has introduced qualitative changes which noticeably affect tourist and residential activity in Spain.

The comparison of certain characteristics related to the profile and behaviour of tourists who travel with LCCs and those who do so with traditional carriers (network and charter carriers) (Fig. 2) reveals striking differences. LCC users mostly organise their trip individually, as shown by the lower percentage who decide to buy package tours and the greater use of the Internet as a source of information while preparing the trip (a feature which becomes even more visible if one pays attention to the purchases/payments made through the Internet: $46.7 \%$ of LCC passengers and only $17 \%$ of those travelling with traditional companies). The type of accommodation varies too: while users of traditional companies clearly prefer hotel accommodation, the percentage of tourists travelling with LCCs who use hotels is much lower, as they tend to opt for accommodation in tourist housing units (free houses of relatives and friends 17\%-, owner-occupied houses $-12.7 \%$ - and rented houses -11.6\%-). Although with a 
less differentiated behaviour, a higher frequency of trips to Spain can be checked along with a greater prevalence of leisure and holiday as the main reasons for travelling among LCC passengers, all of them circumstances which help, though slightly, to reduce the seasonality of tourism flows. The differences in average stay length and available income are not significant, since both segments participate in the most frequent average stay (4-7 nights) and present a practically homogeneous available income level (around $65 \%$ of the demand belongs to the middle class in both segments).

Fig. 2. A comparison of certain characteristics related to the profile and behaviour of tourists (LCCs and Traditional Companies)

In relation to expenditure levels at the destination, tourists arriving with LCCs show an average spending per person of 65.9 euros less and an average spending per person per day of 9.2 euros less than traditional airline passengers (IET, 2005). This circumstance has led to a negative valuation of the increased LCC traffic due to their lesser economic contribution to destination areas. Exceltur, an alliance for tourism made up of 26 Spanish business organizations among which stand out Iberia, Air Nostrum, Iberostar, Amadeus, Sol Melià or Riu Hotels \& Resorts, summarises the impacts caused by LCCs in a greater use of non-hotel accommodation and a decrease both of the average stay length and of the average spending per tourist (DELOITTE-EXCELTUR, 2005). This business alliance formed by traditional airlines, tour operators and hotel groups has softened its criticism of LCCs to value positively the dynamism of the international market thanks to the improved accessibility levels derived from the greater availability of air connections and the higher frequency of trips to Spain (EXCELTUR, 2006). 
Rather than a cause-effect relationship in which LCC expansion would cause a drop in the spending level per tourist and a decrease in the socioeconomic profitability of tourism, a confluence between factors takes place which can further intensify real estate specialisation in certain stretches of the Spanish coast: urban development growth; demand loyalty; increased residentialism, investment appeal of property acquisition; a better air connectivity in terms of frequencies and prices; or the direct commercialisation of the accommodation supply through the Internet. It has been estimated from the 2001 housing census that beds in second residences represented $82.2 \%$ of the total accommodation supply (VARELA et al., 2003). This supply structure, based on private accommodation, should be related to the average expenditure per tourist, which is $13.5 \%$ lower than the average expenditure of tourists who use hotels (IET, 2005). On the other hand, according to the air carrier segmentation made by the IET (2004), the companies generating more tourist arrivals in Spain are the ones which carry the leisure segment without package tours and non-hotel accommodation. This segment includes the airlines Easyjet and Ryanair among others and represents a $34.2 \%$ of the total tourist arrivals in LCCs. They mainly operate at destinations situated along the Mediterranean coast with a clear predominance of accommodation in tourist housing units $(74.7 \%$ in Catalonia, $83.7 \%$ in Andalusia and $91.2 \%$ in the Valencia Region).

Additionally, the greater number of links with regional airports has stimulated the demand for city breaks in Northern Spain (Santiago de Compostela, Santander or Bilbao) or the Mediterranean (Valencia) and has improved their positioning in this expanding European market. It has also facilitated the growth of the Spanish emitting market toward the main European urban destinations, usually well connected by LCCs. 
These companies have fed the tourist-residential migratory flows toward Spain in the different types of mobility distinguished by WILLIAMS and HALL (2002): productionled (labour and entrepreneurial) and consumption-led (economically active migrants and retirement migration, from seasonal to long-term and permanent migration). The case of the Alicante airport could be illustrative in this respect. Its area of influence (South of Valencia and North of Murcia) integrates main mass tourism destinations such as Benidorm and an important contingent of foreign residents. According to the figures provided by the Aena-Alicante airport mobility survey, five passenger segments have been created using an a priori methodology (foreigners using hotel accommodation; foreigners using non-hotel accommodation; foreign residents in Spain; domestic leisure passengers, and domestic professional passengers) (VERA, 2005). A comparison has been drawn between the extent to which each type of company (network, charter and LCC) was used in two different time periods: 2002 and 2004. This study gives information about LCC use by residents, an aspect which has hardly been analysed in Spain despite its growing relevance.

Fig.3. LCC use evolution by type of passenger at Alicante Airport (\%)

LCC use grew in all segments during the 2002-2004 period. The main group, which includes international tourists using a non-hotel accommodation (50.4\% of the total traffic), showed an important growth, the same as that of international tourists accommodated in hotels. Both inbound tourism groups have increased LCC use through organic growth and charter company substitution. Foreign residents in Spain are the ones which mostly use LCCs, the use by Spanish citizens being still low but growing rapidly, especially in the case of international leisure trips. Concerning Spanish and 
foreign residents' trips, the appearance of LCCs seems to have affected network companies mainly, an impact that will become more visible in the near future according to the foreseeable growth of LCC domestic routes.

\section{TOURISM AND REGIONAL POLICIES IN SPAIN: AN EVOLUTION SYNTHESIS}

Regional policy development in Spain presents two main landmarks during the last quarter of the 20th century: (1) the 1978 Constitution (after the end of Franco's dictatorship (1939-1975)), which laid down the foundations for the political and administrative decentralisation of the country; and (2) the entry into the European Economic Community (EEC) in 1986. Joining the EEC meant a reorganisation of regional policy instruments that became more effective through the implementation of the Community Support Frameworks (CSFs), the Regional Development Plans (RDPs) and the Regional Restructuring Plans (RRPs) and, especially, through the direct access to the European Structural Funds mainly in Objective-1 regions.

The percentages of surface and population that benefited from these instruments are significant. RDPs have been applied to Objective-1 regions (those with a GDP per inhabitant situated below $75 \%$ of the European Union average) -approximately $77 \%$ of the national surface and $58 \%$ of the total Spanish population. As for RRPs, they benefit Objective-2 regions (identified since the 1999 reform of Structural Funds as areas affected by industrial decline or disadvantaged rural areas), involving around $20 \%$ of the Spanish population. According to the figures given by the Spanish Ministry of Finance, Spain will receive a total amount of 55,025 million euros (from 1999) from European Structural Funds for the 2000-2006 period. However, the recent enlargement of the EU will reduce the number of Objective-1 regions due to the statistical effect of this enlargement and to the economic evolution of certain regions. The role of tourism 
in Spanish regional policies could be better understood through the analysis of CSFs. Even though the Funds directly received for tourism investments have been scarce, the benefits are evident in terms of the investments made in infrastructure, human resource training or entrepreneurial support.

The first CSF (1989-1993) recognised the economic importance of tourism through RDPs and RRPs, and not only in coastal regions with a high tourism development level. The second CSF (1994-1999) tried to avoid the effects of a structural imbalance between the Spanish supply and the evolution of international demand, which showed clear signs of stagnation in the late 1980s. The modernisation of the tourism supply and the adaptation to the new demand trends are priority aspects of the tourism policy within a context of diversification and spatial diffusion of Spanish tourism. The third CSF (2000-2006) has confirmed the progressive consolidation of regional tourism models not only in coastal areas but also in inland regions, thus contributing to redress territorial economic activity imbalances.

The economic and monetary union in Europe makes it difficult to compete in a global tourism market through the use of low prices, which means that quality improvement becomes a strategic goal for Spain's tourism policy, together with sustainability, even though the latter concept is often used in a rhetorical way.

Two geography-based approaches to tourism can be distinguished in relation to regional development strategies (IVARS, 2003): that of the Autonomous Communities (Regions) where tourism is basically a strategic sector: mainly the Mediterranean coast and the Balearic and Canary archipelagos, mature tourist spaces which are going through a restructuring and diversification process with the aim of maintaining their competitiveness; and that of those located in inland Spain and the Atlantic façade, where tourism is an emergent sector which can contribute to the diversification of the 
productive structure and the dynamisation of regressive productive tissues (industrial spaces or underprivileged rural areas).

\section{TOURISM AND REGIONAL DEVELOPMENT POLICIES RELATED TO LCCs}

The introduction of LCCs has mainly taken place in tourist regions located along the Mediterranean coastline. However, LCC presence is also significant at airports situated in Autonomous Communities with an emergent tourist activity. The Atlantic Arc Transport Group (2005) made a positive valuation of the impact that LCCs have had on the improvement of connectivity between the airports located in the Atlantic area and large capitals and tourist destinations; on the maintenance of airport infrastructures which remain open all year round; and on the positive evolution of tourism, new activities and real estate investments. Generally speaking, Tourism Administrations and business associations share a positive perception of the opportunities derived from the traffic increase caused by LCCs, as shown by the concession of a series of public incentives in the fields of advertising and promotion which, therefore, are not affected by the above-mentioned 2005 European Commission Communication.

Among the promotion agreements signed by seven airports in 2005 stand out the aids and subsidies granted by regional governments, with the support of business associations, to the company Ryanair in Girona (5.5 million euros between 2004 and 2005) and Santiago de Compostela (3.7 million euros for the $2005-2008$ period). These incentives are not exclusive of LCCs, as other Autonomous Communities have equally signed promotion agreements with regional airlines. An example can be found in the funds received by the carrier Air Nostrum in the Valencia Region. 
Nevertheless, the effects of LCC operations go beyond tourism policy and directly affect land-use regulations and infrastructure planning, thus generating new dynamics mainly linked to the urban development of Mediterranean coastal spaces. The real estate sector related to the tourism and leisure market has become the true pillar of economic growth in the Mediterranean and Island regions since, to the abundant and growing external demand can be added a considerable volume of sales oriented toward local residents. Furthermore, whereas the first-home sector tends to slow down, the holidayhome sector continues to grow. It suffices to mention that more than 1.2 million new housing units were built in the Mediterranean coastal regions between 1992 and 2000. Thus, in the whole of the Spanish territory, with the exception of Madrid, the bulk of residential construction activity has taken place along the Mediterranean coastline. Over $50 \%$ of the new residential building activity during the last decade corresponds to the Mediterranean façade, a percentage which rose to nearly $60 \%$ in the last few years (MINISTERIO DE FOMENTO, 2004).

In this context, LCCs have contributed to develop new initiatives regarding airport infrastructures. They have mainly boosted the need for adaptation and enlargement of the Spanish airports integrated in the State network and promoted private investments with the direct support of regional governments. Examples are the new airports to be built in Castellón and Murcia.

The Castellón airport is a public-private initiative which arose despite Spain's national airport planning. After all, the Ministry of Public Works Master Plan of the 1990s did not foresee an increase in the number of airports but an improvement of the existing ones with a special focus on the optimisation of the often wasted airport operating capacity. In the case of Castellón, a linear relationship exists between the tourist- 
residential development model shaped along the northern coast of the province, with large developments foreseen, and the role of the air traffic channelled by LCCs.

The case of the Murcia Region shows a more categorical repetition of the same scheme of relationships between urban development processes, regional development policies and large-scope plans for the construction of a large international airport, the dynamics of which is associated with the role of LCCs. The alliance between low-cost carriers and the residential development model is essential, since the product is offered as holiday housing with an easy access from the users' places of permanent residence.

In 2004, the regional government approved the Guidelines and Coastal Plan for the Murcia region, which lays the foundations for the real estate development of Murcia's coastal and pre-coastal areas. Among the so-called strategic actions stands out the new Corvera international airport and the construction of "Marina de Cope", a project that has been described as the largest tourist complex in Europe: 9,000 dwellings, 20,000 hotel places, 5 golf courses and an inner marina with 2,000 berths (VERA \& ESPEJO, 2006). These actions are complemented with the building of new highways which connect both with the traditional Mar Menor destinations and with the new urban developments in the Southern coast of Murcia (Cartagena-Vera motorway), as well as with those which are gradually appearing in agricultural coastal areas under the golfresort modality (integrated residential complexes including service equipment where golf courses represent the main appeal (Fig.4).

Fig.4. Guidelines and Coastal Plan for the Murcia Region

The magnitude of the process becomes evident when one looks at the facts and figures about the projects analysed: over 80,000 housing units and a number of potential 
residents which could exceed 200,000 if the most substantial part of the projects presented or under construction are executed. The urban development growth associated with golf courses generates demand volumes which are incompatible with the water deficit in South-Eastern Spain and, after the cancellation of the Ebro-Segura river transfer, paves the way for the achievement of non-conventional water resources, mainly through desalination plants which are projected both by the Ministry of the Environment and by private entrepreneurs. The regional development strategy decidedly bets on the 'construction-residentialism-tourism' trinomial despite the water deficit and the environmental impact associated with real estate development that has even led to the reduction of the protected perimeter of the Cabo Cope Natural Park. The construction of new infrastructures is put at the service of a growth model based on a de-territorialised type of supply (autonomous residential complexes around a golf course) which notably alters the pre-existing territorial structure as a result of the transformation of vast stretches of agricultural land and to the vast capacity of some complexes, the population of which exceeds that of the neighbouring traditional urban nuclei. This strategy is hardly compatible with the principles of sustainable development, which requires a growing investment in public infrastructures and services and additionally depends on the maintenance of the international demand for the purchase of properties, probably overrated by real estate developers and the regional government.

The idea of constructing new regional airports as a key piece in the productive tissue dynamics is present in other projects along the Mediterranean. One can highlight the project of an airport in Huelva (Western Andalusia). It is a space characterised by a peripheral location, although the improved accessibility by road makes it possible to use the international airports of Seville and Faro (Portugal), which are just over 100 
kilometres away. But the essential argument for the project of a new airport, according to its supporters, is the need to optimise an efficient logistics for the tourist and residential destinations that are being developed in this region (MÁRQUEZ and JURADO, 2005). It is, thus, another case where the interests related to large tourist developments (golf is the 'star product') are closely linked to the proximity of an airport and the new opportunities generated by LCCs.

The Don Quijote airport (in Ciudad Real), a private-initiative-based infrastructure too, was declared a regional-interest project by the regional government of Castille-La Mancha and is due to start operating in 2006. Its location in the centre of the Iberian Peninsula is determined by a relative proximity to Madrid (198 kilometres) and by the connection with the Madrid-Seville high-speed train line through the creation of a station inside the passenger terminal. The media have associated this airport with the establishment of a new Ryanair base in Spain (in addition to Girona) to compete for the traffic generated by Madrid. Nevertheless, the cost of the trip in the high-speed train to the capital and the recent enlargement of Madrid-Barajas airport, which will facilitate a greater presence of LCCs, may hinder this strategy.

Apart from the already mentioned projects, the spread of LCCs in Spain has also affected the public air transport planning system, managed by the public company known as AENA (Fig. 5). Special importance is assigned to finding a solution to capacity shortages in tourist airports (Alicante, Málaga, Almería, Murcia-San Javier, etc.), both in the RDP (2000-2006) and in the Infrastructures Plan (2000-2007). However, LCC traffic growth has anticipated the problem provoking, for instance, the building of a provisional terminal at the Alicante airport to deal with the traffic increase until the completion of a definitive airport enlargement. The Strategic Infrastructures and Transport Plan (2005-2020) sets as a priority for air transport to encourage LCC 


\section{CONCLUSIONS}

The introduction of LCCs in Spain has accelerated certain processes, among which stands out the specialisation of Mediterranean coastal destinations in real estate. The imbalance between the hotel supply volume and the capacity of tourist housing units is an essential feature of Spanish tourism. The high urban development growth rates, largely linked to foreign investment in property, are closely related to the improved air accessibility via enlargement of existing airports or creation of new ones. LCC expansion has brought forward the enlargement plans for tourist airports and has especially favoured the appearance of private initiatives, supported by regional governments, which have meant significant changes in Spain's public-owned and staterun airport national network, that is dependent on the Central Administration.

Although the privatisation of airports does not seem to be a short-term or medium-term objective in Spain, pressures for the intervention of regional governments and private 
agents in airport management are becoming stronger. The possibilities offered by LCCs reinforce this demand, which materialises in the concession by regional governments of incentives to these companies through promotion agreements, among other things. A new era seems to have started for the relationship between airports, airlines and regional governments in Spain, favoured by the spread of LCCs.

The Mediterranean regions therefore combine the restructuring policies of mature destinations with the maintenance of the real estate-tourist growth processes that increase the pressure upon natural resources and the landscape. This is an approach which not only refers back to the rhetorical use of sustainable development made in the laws, plans and programmes of Public Administrations (with few exceptions, e.g. the Coastal System Plan in Catalonia which, among other specifications, limits building in the first 500 meters from the sea shore) but also has serious sectorial effects. The profitability of hotel enterprises suffers due to the drop in occupancy rates provoked by the increased use of non-hotel accommodation, while at the same time tourist average spending levels tend to decrease. It is advisable to analyse these dynamics and wonder to what extent traditional coastal firms and destinations are adapting properly to the new tourism scenario which, among other factors, foresees LCC expansion.

Finally, attention should also be paid to the effects of the consolidation and possible saturation of the low-cost market in Europe, and in short, to the sustainability of this business model (BINGGELI and POMPEO, 2002, 2005; DENNIS, 2004; GORDON et al. 2005) and its effects on traffic evolution. The numerous failures and the volatility associated with the decisions adopted by LCCs make necessary a prior rigorous analysis of the agreements signed between carriers, airports and regional governments and, above all, of the different public policies related to the low-cost traffic. 


\title{
REFERENCES
}

\begin{abstract}
ATLANTIC ARC TRANSPORT GROUP (2005): Study of the impact of low-cost services in the Atlantic Arc Regions, Nantes, June 2005, Conference of Maritime and Peripheric Regions of Europe
\end{abstract}

ALBERS, S., KOCH, B. and RUFF, Ch. (2005): Strategic alliances between airlines and airports - theoretical assessment and practical evidence, Journal of Air Transport Management, 11, 49-58

AVIATION STRATEGY (2003): Airports: industry trends and key privatisation issues, Aviation Strategy, October, 2003, 6-10

BAKER C., FIELD D. and IONIDES N. (2005): Global Reach, Airline Business, May $2005,60-65$

BARRETT, S. (2004): How do the demands for airport services differ between fullservice carriers and low-cost carriers?, Journal of Air Transport Management, 10, 33-39 BINGELLI, U. And POMPEO (2005): Hyped hopes for Europe's low cost airlines, The McKinsey Quarterly, August, Available from: www.mckinseyquarterly.com

BINGELLI, U. And POMPEO (2002): The battle for Europe's low-fare flyers, The McKinsey Quarterly, 4, 86-97

DENNIS, N. (2004): An easy Ride so Far: How Sustainable is the Low-Cost Airline Business Model in Europe?, January 2004, UTSG

DOBRUSZKES F. (2005): An analysis of European low-cost airlines and their networks, Journal of Transport Geography, Article in Press, Available from: www.sciencedirect.com 
DELOITTE-EXCELTUR (2005): Estudio de los impactos socioeconómicos, ambientales y sobre el empleo del actual modelo de desarrollo turístico español del litoral mediterráneo, Baleares y Canarias”, Madrid, Exceltur

EUROCONTROL (2006): Low Cost Carrier Market Update, December 2006, available from www.eurocontrol.int/statfor

EUROCONTROL (2005): Low Cost Carrier Market Update, September 2005, available from www.eurocontrol.int/statfor

EXCELTUR (2006): Perspectivas Turísticas, 17, July 2006, available from www.exceltur.org

ESECA (2006): Estudio sobre el impacto económico de las líneas aéreas internacionales en Granada, Granada, Diputación de Granada

EUROPEAN LOW FARES AIRLINE ASSOCIATION (ELFAA) (2004): "Liberalisation of European Air Transport: The Benefits of Low Fares Airlines to Consumers, Airports, Regions and the Environment", Brussels, European Low Fares Airline Association

FRANCIS, G., HUMPHREYS, I and ISON, S. (2004): Airports' perspectives on the growth of low-cost airlines and the remodeling of the airport-airline relationship, Tourism Management, 25, 507-514

FRANCIS, G., HUMPHREYS, I and ISON, S. (2003): Airport-airline interaction: the impact of low-cost carriers on two European airports, Journal of Air Transport Management, 9, 267-273

GÁMIR A. and RAMOS D. (2002): Transporte aéreo y territorio, Barcelona, Ed. Ariel GILLEN, D. and LALL, A. (2004): Competitive advantage of low-cost carriers: some implications for airports, Journal of Air Transport Management, 10, 41-50 
GORDON, D., BLAZA, A. and SHEATE, W. (2005): A Sustainability risk analysis of the Low Cost Airline sector, World Transport Policy \& Practice, Vol. 11, 1, 12-33

GRAHAM A. (2003): Managing airports. An international perspective, Oxford, Elsevier, $2^{\text {nd }}$ edition

GRAHAM, B. (1999): Airport-specific traffic forecasts: a critical perspective, Journal of Transport Geography, 7, 285-289

HAKFOORT, J. , POOT, T. and RIETVELD, P. (2001): The Regional Economic Impact of an Airport: The Case of Amsterdam Schiphol Airport, Regional Studies, Vol. $35.7,595-604$

INSTITUTO DE ESTUDIOS TURÍSTICOS (IET) (2006): Compañías aéreas de bajo coste, 2005, Madrid, Ministerio de Industria, Turismo y Comercio, Secretaría General de Turismo

INSTITUTO DE ESTUDIOS TURÍSTICOS (IET) (2005): Encuesta de gasto turístico. Año 2004, Madrid, Ministerio de Industria, Turismo y Comercio, Secretaría General de Turismo

INSTITUTO DE ESTUDIOS TURÍSTICOS (IET) (2004): Compañías aéreas de bajo coste, 2003, Madrid, Ministerio de Industria, Turismo y Comercio, Secretaría General de Turismo

IVARS, J. (2003): Regional development policies: an assessment of their evolution and effects on the Spanish tourist model, Tourism Management, 24, 655-663 MÁRQUEZ J. and JURADO J. (2005): Factores espaciales, productivos y logísticos para un aeropuerto en la provincia de Huelva, Huelva, Universidad de Huelva MARTÍNEZ E. PRATS Ll. and BARCELÓ M. (2004): El perfil de l'usuari dels vols de baix cost de l'aeroport de Girona, Girona, Universitat de Girona 
MINISTERIO DE FOMENTO (2004): Anuario Estadístico 2003, Madrid, Ministerio de Fomento

OAG (2006): "European Low Cost Carriers White Paper", available on http://www.oag.com

PANTAZIS, N. and LIEFNER, I. (2005): The impact of low-cost carriers on catchment areas of established international airports: The case of Hanover Airport, Germany, Journal of Transport Geography, in press

PITT, M. and BROWN, A. (2001): Developing a strategic direction for airports to enable the provision of services to both network and low-fare carriers, Facilities, 19, 1$2,52-60$

SIGNORINI, A., PECHLANER, H. and RIENZNER, H. (2002): The impact of a low fare carrier on a regional airport and the consequences for tourism. The case of Pisa, KELLER, P. and BIEGER, Th. (eds), Air Transport and Tourism, 52 ${ }^{\text {nd }}$ AIEST Congress, Vol. 44, 185-226

SQW (2002): Economic and social impact of no frills air services in the Highlands and Islands, Edinburgh, Highlands \& Islands Enterprise and Highlands \& Islands Airports Limited

VARELA, B. LÓPEZ, A. and MARTÍNEZ, A. (2002): Primeras aproximaciones al estudio estadístico del alojamiento privado con fines turísticos desde una perspectiva de la oferta, Estudios Turísticos, 155-156, 87-109

VERA, J.F. (2005): Análisis del perfil del pasajero de las compañías de bajo coste en el aeropuerto de Alicante, Unpublished, Research requested by AENA to Alicante University

VERA, J. F. and ESPEJO, C. (2006): "El papel de los instrumentos de planificación en las dinámicas productivas y territoriales: las Directrices y el Plan de Ordenación del 

territorial en España, Valencia, Universidad de Valencia, pp. 61-79

WILLIAMS G., MASON K. and TURNER S. (2003): Market Analysis of Europe's Low Cost Airlines. An examination of trends in the economics and operating characteristics of Europe's charter and no-frills scheduled airlines, Air Transport Group, Cranfield University

WILLIAMS, A. and HALL, M. (2002): Tourism, migration, circulation and mobility, in WILlIAMS, A. and HALL, M. (eds), Tourism and Migration. New relationships between Production and Consumption, Dordrecht, Kluwer Academic Publishers, 1-52 
Figure 1

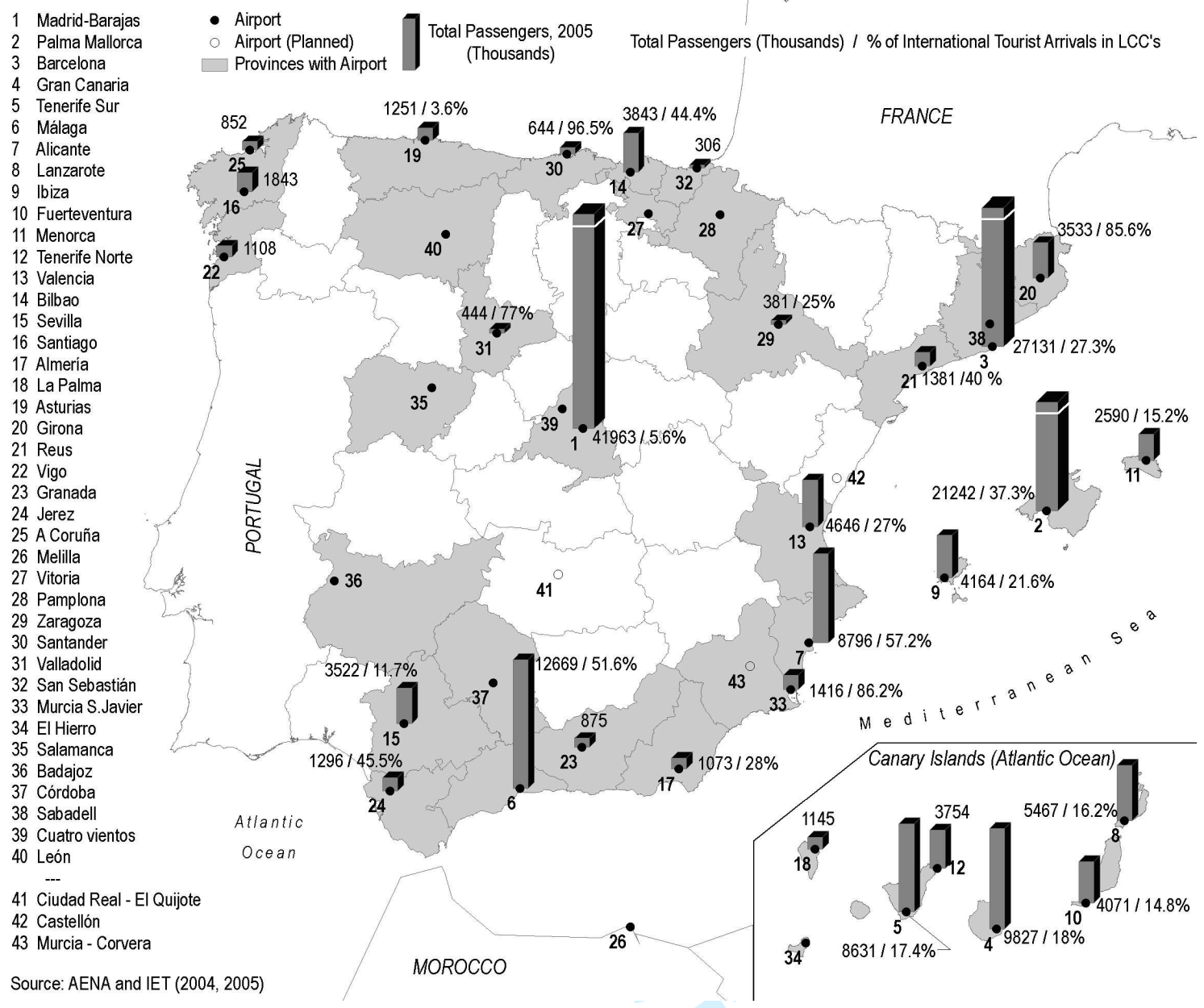


Figure 2

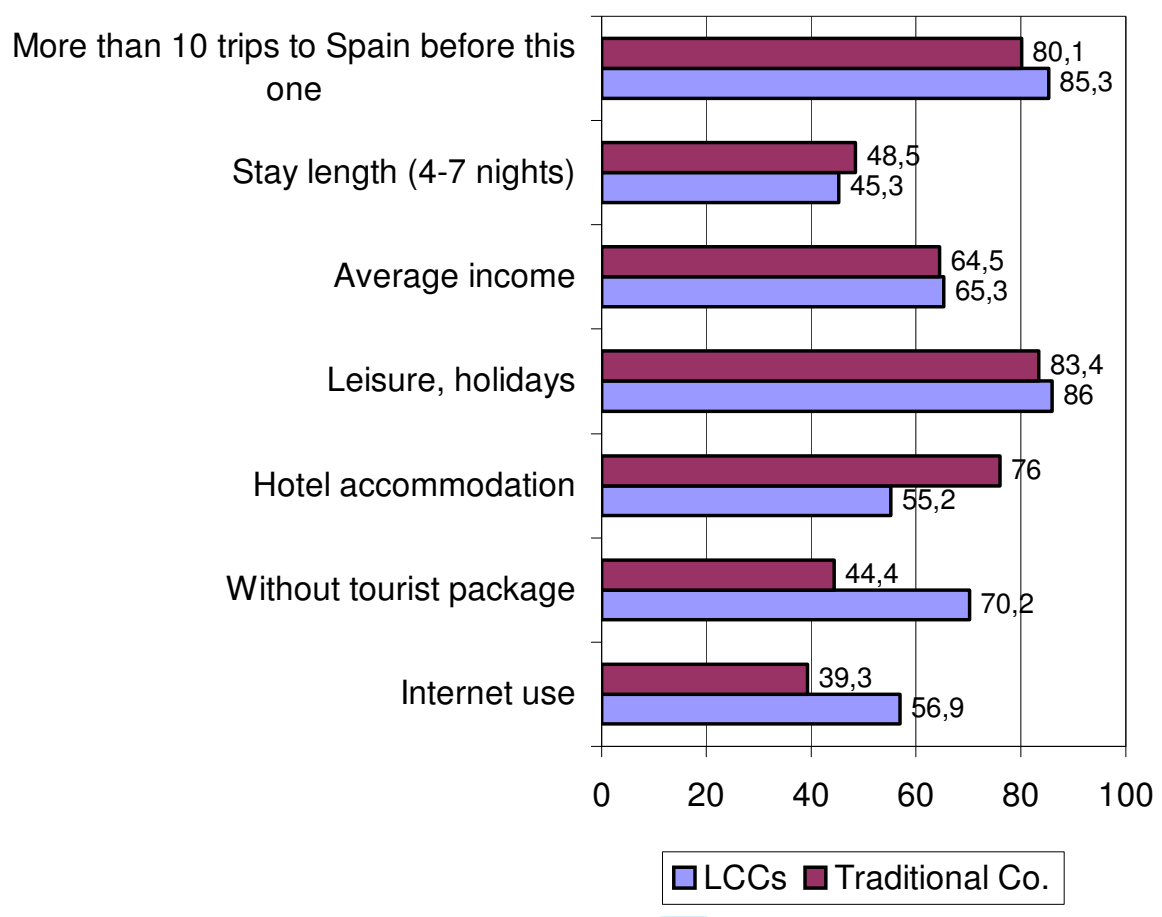

Source: Instituto de Estudios Turísticos (2005) 
Figure 3

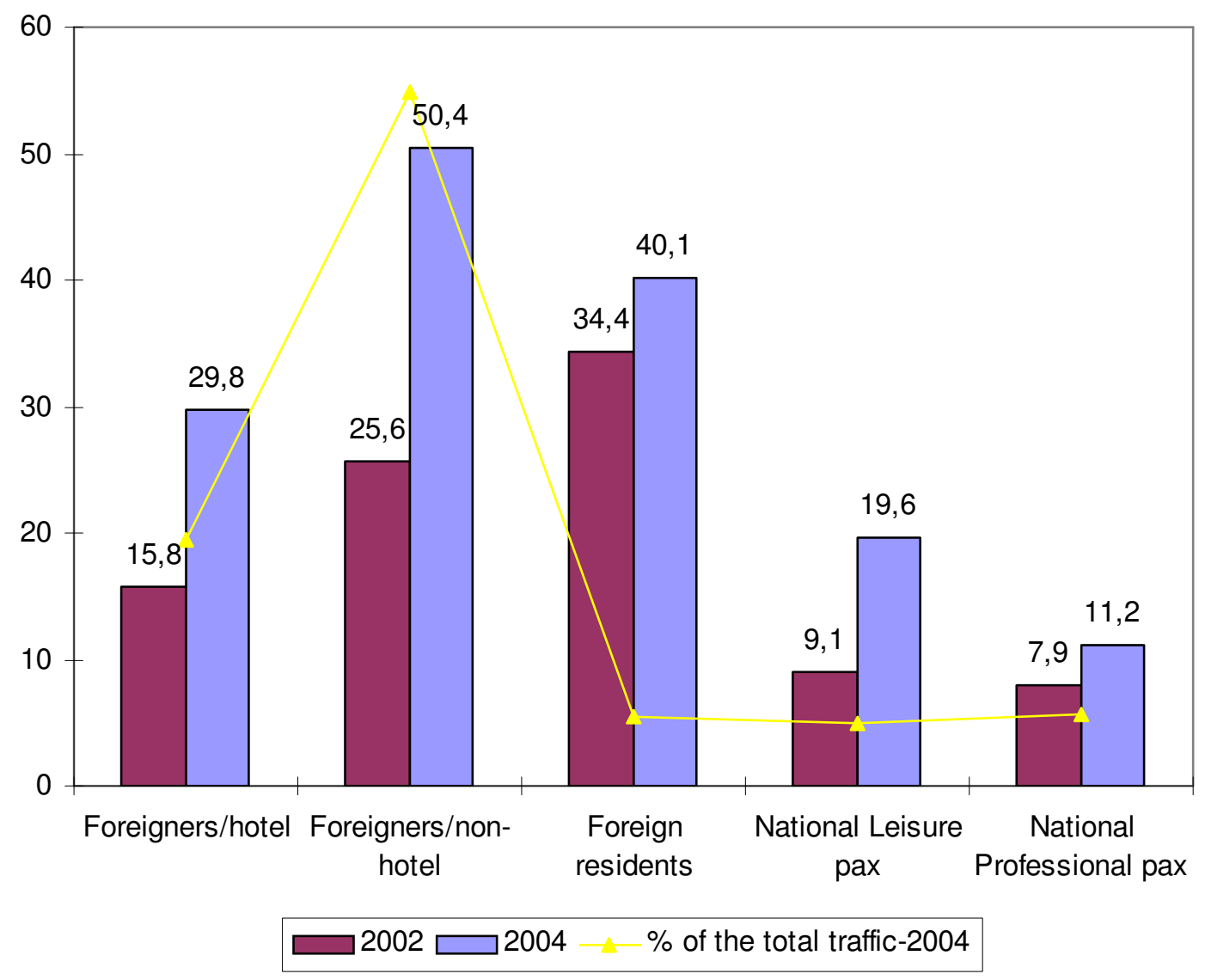

Source: AENA-Alicante Airport 
Figure 4

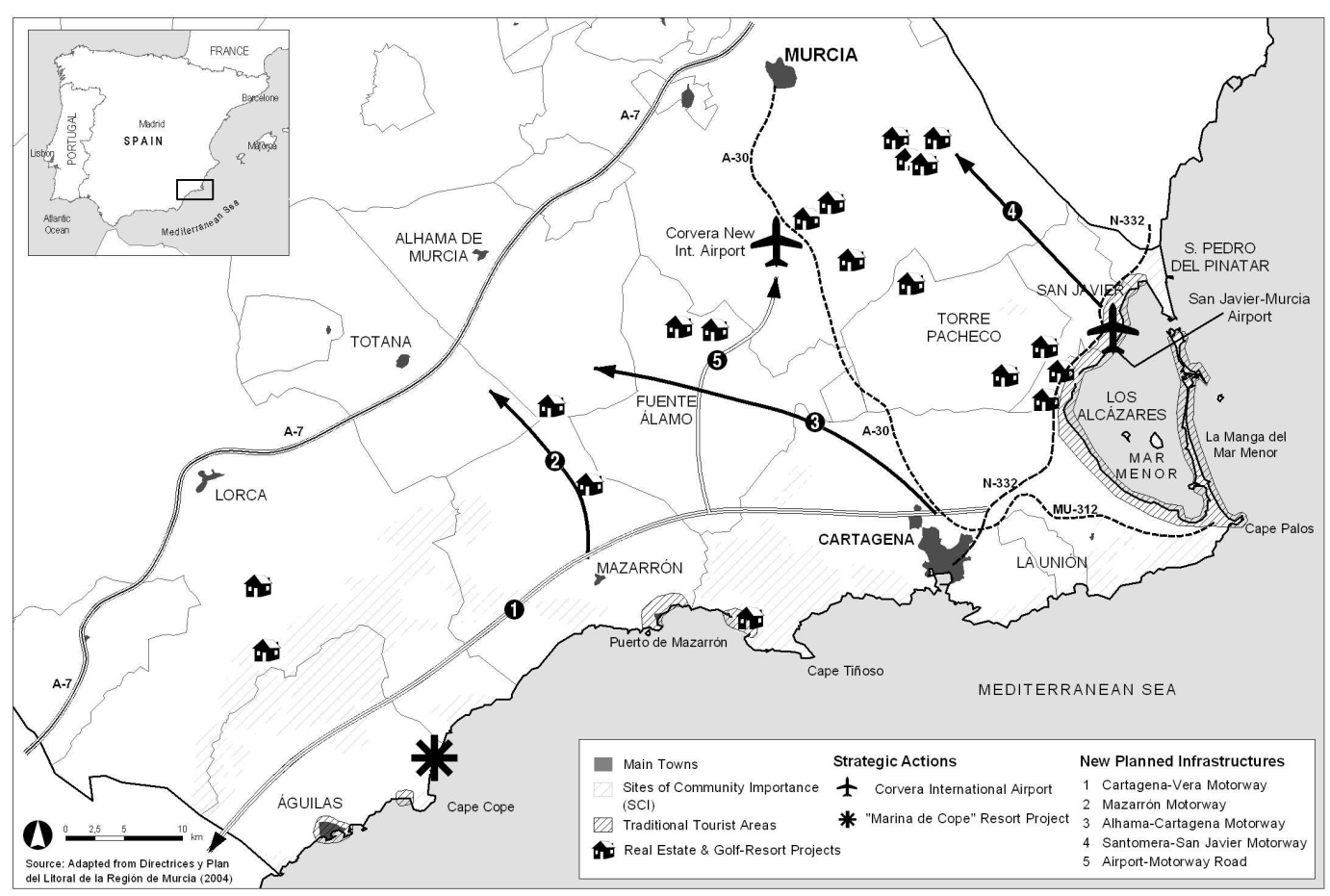


Figure 5

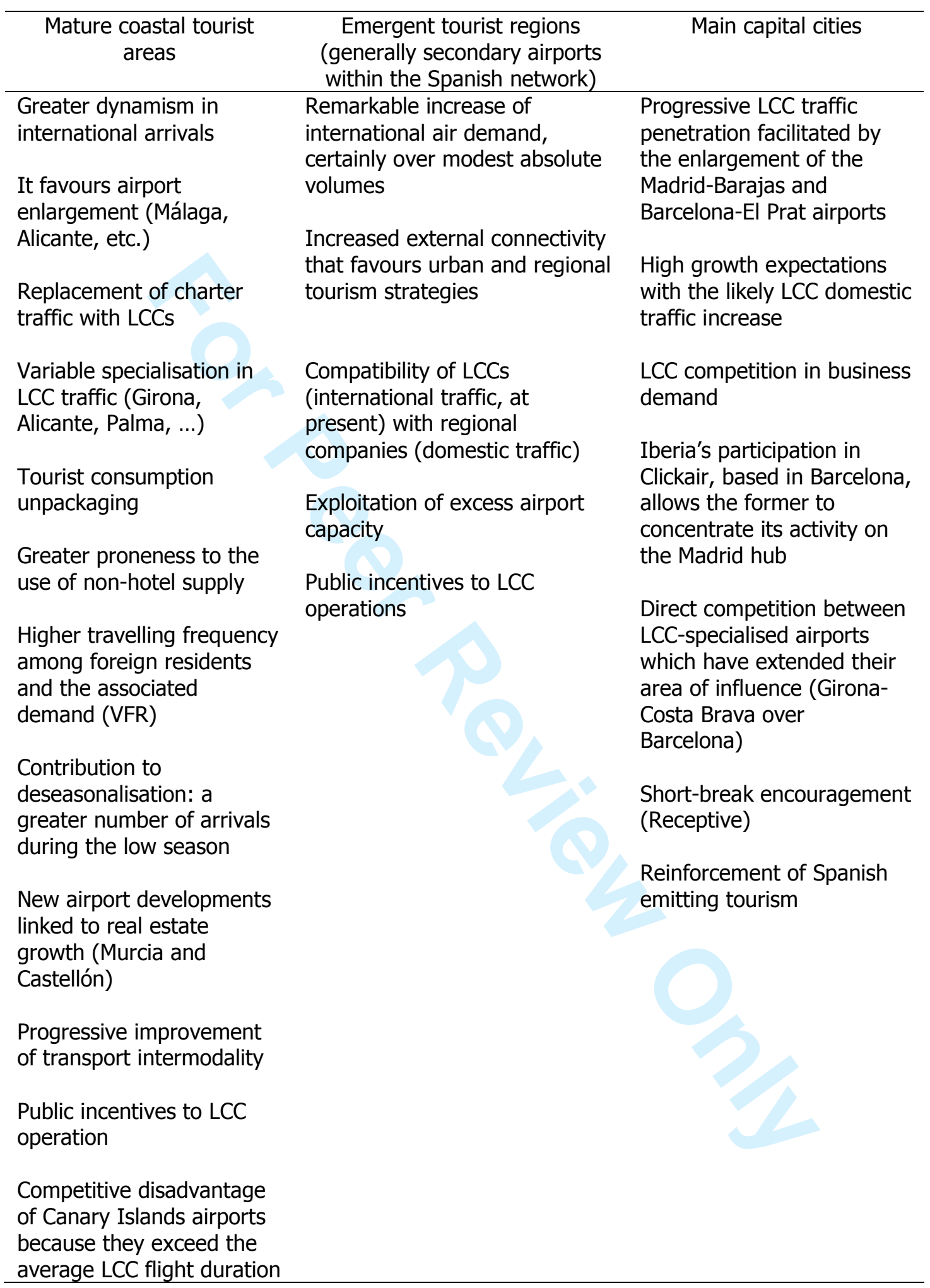

